\title{
Marketing educacional: propostas e desafios para uma instituição de educação básica
}

\author{
Educational marketing: proposals and challenges for a basic education institution
}

\author{
Fabrício Forcato dos Santos ${ }^{* 1}$; Rosebelly Nunes Marques ${ }^{2} \oplus$
}

Recebido: out. 24, 2019

Aceito: jul. 10, 2020

${ }^{1}$ Colégio Passionista Nossa Senhora Menina - Mestre e Graduado em História pela Universidade Federal do Paraná - Rua Bom Jesus, 881 A - Cabral - CEP 80035010 - Curitiba (Paraná), Brasil.

\footnotetext{
${ }^{2}$ Universidade de São Paulo - Doutora em Educação pela Faculdade de Ciências e Letras da Unesp/Araraquara. Doutora em Química pelo Instituto de Química da Unesp/ Araraquara. Professora, RDIDP, da Universidade de São Paulo (USP), na Escola Superior de Agricultura Luiz de Queiroz (ESALQ), do Departamento de Economia, Administração e Sociologia - Avenida Pádua Dias 11 - CEP 13418900 - Piracicaba (São Paulo), Brasil.
}

*Autor correspondente <fforcato@gmail.com>

Este é um artigo publicado em acesso aberto (Open Access) sob a licença Creative Commons Attribution, que permite uso, distribuição e reprodução em qualquer meio, sem restrições desde que o trabalho original seja corretamente citado.

\begin{abstract}
Resumo: Tendo em vista o crescimento do número de empresas particulares atuantes na área da Educação, especialmente na educação básica, as ações de marketing realizadas nesse segmento são instrumentos importantes no que diz respeito ao posicionamento e competitividade no mercado. $\mathrm{O}$ objetivo deste trabalho, dessa forma, foi o de discutir os aspectos promoção, pessoas e evidências físicas do composto de marketing de uma instituição privada de educação básica e propor algumas estratégias dentro do marketing educacional. Para tanto, foram utilizados dados provenientes de pesquisas de satisfação e de relatórios internos sobre retenção e captação de novos clientes por parte da unidade educativa. As informações mostraram que, em decorrência das características particulares dos serviços, a instituição pode adotar medidas que não impactam profundamente seu planejamento e que possibilitam ampliar o grau de satisfação da sua clientela com consequente aumento da fidelização.
\end{abstract}

Palavras-chave: planejamento educacional; estratégia de mercado; competitividade.

\begin{abstract}
There has been a growth in the number of private companies active in the area of Education, particularly Basic Education. Therefore, the marketing actions carried out in this segment are important instruments in terms of positioning and competitiveness in the market. In this sense, this work aims to examine the marketing mix of a private institution of basic education and discuss the following aspects: promotion, people, and physical evidence. It also aims to propose some strategies with regard to educational marketing. To this end, I used the following data from that educational institution: satisfaction surveys, and internal reports on the retention and attraction of new clients. The information showed that, due to the particular characteristics of the services, the institution can adopt measures that, apart from not having a profound impact on its planning, allow for the increase in the degree of satisfaction of its clients, and for a consequent increase in loyalty.
\end{abstract}

Keywords: educational planning; market strategy; competitiveness. 


\section{Introdução}

O mercado de serviços educacionais relacionados à educação básica tem crescido no Brasil nos últimos anos. Conforme dados apontados pela Pesquisa Nacional por Amostra de Domicílios Contínua em 2016 (PNAD, 2016), no Brasil cerca de 56,6 milhões de pessoas frequentavam escola ou creche. Ainda de acordo com esse levantamento, as taxas de escolarização entre indivíduos de 0 a 3 anos, 4 e 5 anos, 6 a 14 anos e de 15 a 17 anos atingiram, nesse ano, respectivamente, 30,4\%, 90,2\%, 99,2\% e 87,2\%. A maioria dos estudantes brasileiros (73,5\%) frequentaram, no período, a escola pública, e os outros $26,5 \%$ estavam matriculados em instituições de ensino privadas. A concentração do número de estudantes em rede particular ou privada variou naquele ano de acordo com a região, e a região sudeste apresentou maior porcentagem de alunos matriculados na rede privada de ensino do que as demais regiões do país: $30,1 \%$. Na região sul, na qual se encontra o objeto de estudo deste trabalho, tem-se que $26,8 \%$ dos alunos frequentaram, em 2016, instituições privadas de ensino, índice que superou, inclusive, a média nacional de estudantes da rede privada no período ${ }^{1}$.

Analisando atividades de marketing educacional, Carneiro (2015) destacou que além da massificação da educação nas últimas duas décadas, o desenvolvimento de tecnologias de informação e comunicação, a expansão do ensino privado e a redução de financiamentos públicos são pontos que permitiram a ampliação dos serviços ofertados por instituições privadas de ensino. 0 crescimento dessas instituições é perceptível entre os diversos níveis de educação. De acordo com o Censo Escolar da Educação, realizado pelo Instituto Nacional de Estudos e Pesquisas Educacionais Anísio Teixeira (Inep), divulgado no início de 2018, 21,7\% dos colégios existentes no Brasil eram particulares. Entre eles, o levantamento apontou que o ensino fundamental era ofertado em 116 mil instituições privadas e o ensino médio, por sua vez, oferecido em 28,5 mil colégios da rede privada de ensino. Ainda de acordo com a pesquisa, a participação das escolas da rede privada no mercado de serviços educacionais passou de $21,5 \%$, em 2016, para 21,7\%, em 2017. A título de comparação, em 2014 esse indicador estava em 21\%. Apesar de pequeno, esse crescimento atraiu, e tende a atrair, novos "players" interessados no mercado da educação básica, entre eles empresas que tradicionalmente atuavam apenas no Ensino Superior.

Kotler e Fox (1994) apontaram que as instituições educacionais tomaram consciência da importância do marketing quando o mercado passou por alterações. Dessa maneira, tendo em vista esse crescente mercado e a concorrência que nele consequentemente se desenvolve, o estudo de estratégias e serviços de marketing na Educação constitui parte fundamental do planejamento de empresas que atuam na área. Como apontado por Carneiro (2015), a educação é parte integrante da economia de serviços, cujo beneficiário direto é o estudante e o beneficiário indireto é a sociedade. Portanto, desenvolver estratégias que criem uma relação adequada entre o serviço ofertado por essas instituições e os seus consumidores (beneficiários) é fundamental para empresas que buscam não apenas ser mais competitivas, mas que, também, lutam pelo seu posicionamento e manutenção nesse mercado.

Dessa forma, este trabalho teve como objetivo central discutir elementos do composto de marketing de uma escola privada de educação básica, localizada na cidade de Curitiba-PR. O colégio em questão é uma instituição confessional católica fundada em 1939 e pertence a uma rede educacional vinculada a três Províncias (conjunto dos conventos e casas conventuais de uma ordem religiosa, chefiado por uma provincial). Todas são associações de direito privado, de fins não econômicos e com caráter beneficente, assistencial e filantrópico. Nesse cenário, tem-se que cada unidade educacional gerencia seus recursos oriundos das anuidades. Parte dos recursos financeiros de cada uma das escolas destina-se a manutenção de bolsas de estudo, totais ou parciais, para alunos com baixo poder aquisitivo. Também são realizados repasses de parte dessa verba para as mantenedoras que, em função do caráter filantrópico da rede, fazem a devida aplicação na área assistencial.

O presente estudo buscou propor estratégias de marketing que permitam, sem desconsiderar as especificidades da gestão escolar, aumentar a competitividade dessa instituição privada de educação básica. Para tanto, estabeleceram-se dois objetivos específicos: i) conhecer o público da instituição por meio do uso de dados socioeconômicos fornecidos pela escola e de censos escolares; a partir de

${ }^{1}$ Os dados citados podem ser encontrados, em conjunto com demais levantamentos pertinentes ao tema, no relatório Educação 2016, que faz parte da PNAD. 
pesquisas realizadas internamente, analisar três aspectos específicos do composto de marketing, a saber: promoção (ações de comunicação), pessoas e evidências físicas.

\section{Material e Métodos}

Frente à concorrência que, conforme dados apresentados, tende a crescer, a diferenciação entre as instituições que atuam na área da educação básica é um aspecto relevante em planejamentos de marketing. Assim, entende-se que essas empresas precisam identificar, compreender e manter as diferenças que possuem em relação aos seus competidores como forma de atingir, de maneira eficaz, seu público-alvo. Nessa direção, apurou-se as principais características positivas que o colégio enfocado por este estudo possui a partir de duas pesquisas de satisfação realizadas com os pais dos alunos nele matriculados ao longo do ano de 2018.

A primeira delas aconteceu entre os meses de julho e agosto. Nessa ocasião, utilizou-se a ferramenta Google Forms para elaboração do questionário, que foi enviado aos pais por meio de um aplicativo interno de comunicação e por e-mail aos clientes que não faziam uso da ferramenta (o que correspondia a uma parcela de menos de $3 \%$ do número total de possíveis respondentes da enquete). Dessa forma, conforme Figura 1, o envio do questionário foi precedido por um aviso encaminhado para as 531 pessoas que formavam a comunidade de responsáveis pelos educandos no período de realização da pesquisa.

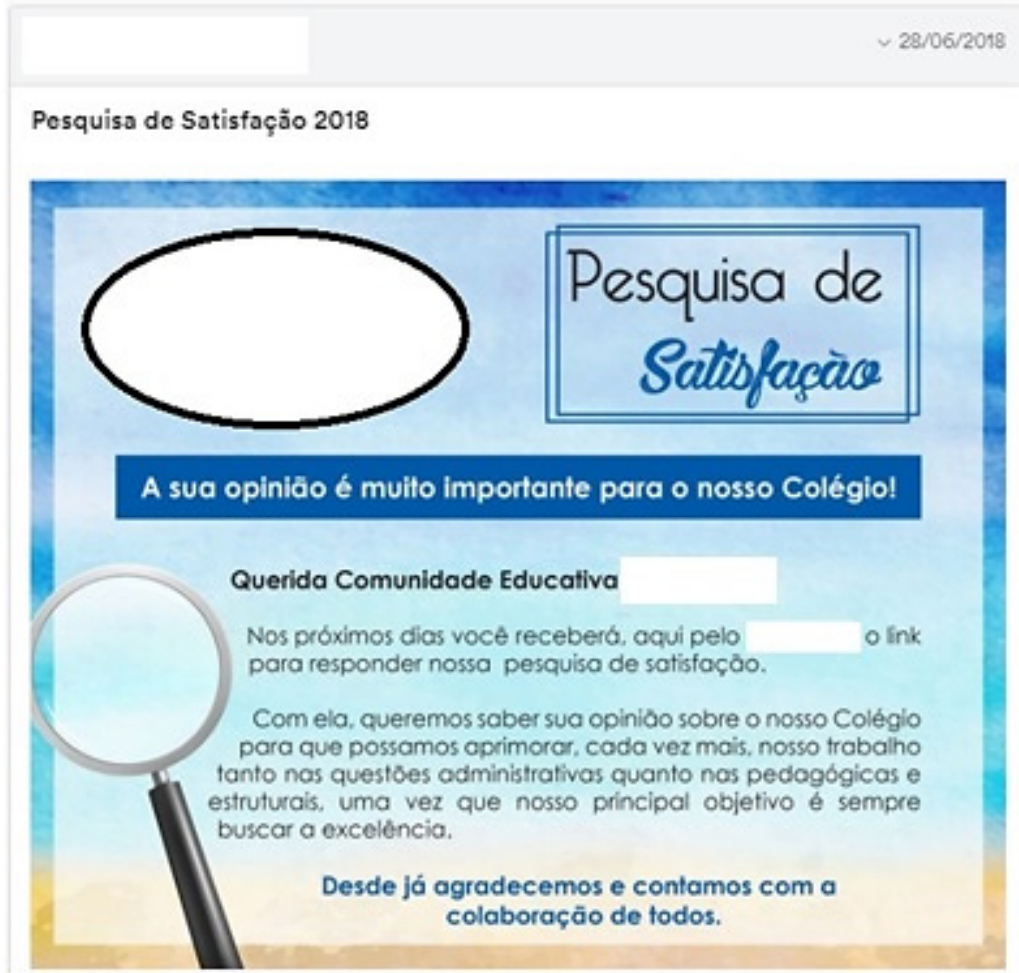

Figura 1. Comunicado de disparo da primeira pesquisa de satisfação do colégio estudado

Fonte: Aplicativo interno de comunicação da unidade educacional

Nota: Algumas informações foram ocultadas pelo autor

O formulário tinha como objetivo auferir informações que permitissem uma avaliação global da instituição. As perguntas eram respondidas de forma anônima e o questionário priorizou indagações objetivas, com espaço aberto para comentários voltados à realização de observações específicas ou sugestões. Entre as áreas avaliadas estavam: i) o corpo técnico docente da instituição (composto pela direção, supervisão pedagógica e coordenações pedagógicas); ii) coordenação de cursos extracurriculares e eventos, orientações educacionais e professores; iii) a perspectiva sobre a disciplina dos alunos; iv) o material didático utilizado nos diversos segmentos de ensino ofertados pelo colégio (Educação Infantil, Ensino Fundamental e Ensino Médio); v) os cursos extracurriculares disponibilizados; vi) a comunicação efetivada pelos funcionários da instituição com as famílias; vii) a aparência física da instituição e sua divulgação; viii) o atendimento realizado pela equipe do colégio, incluindo os parceiros que oferecem 
serviços terceirizados, como a papelaria e o fornecedor de alimentação para os alunos do período integral e; ix) as instalações físicas. Em decorrência do grande número de questões presentes na pesquisa e dos objetivos específicos deste trabalho, optou-se por focar nas indagações que avaliavam o corpo técnico docente do colégio, a comunicação efetivada pela escola, suas instalações e o atendimento realizado pelos funcionários.

Já a segunda pesquisa realizada com os pais dos alunos ocorreu em outubro de 2018 e sua organização coube, conforme Figura 2, a uma empresa privada voltada ao desenvolvimento de uma ferramenta online de comunicação entre escolas e famílias dos alunos. A pesquisa tinha o objetivo principal de medir a satisfação e lealdade dos clientes com base em um questionário formado por catorze perguntas. Entre elas, a indagação sobre a probabilidade de os pais indicarem a instituição a outros responsáveis era considerada quesito principal para essa avaliação.

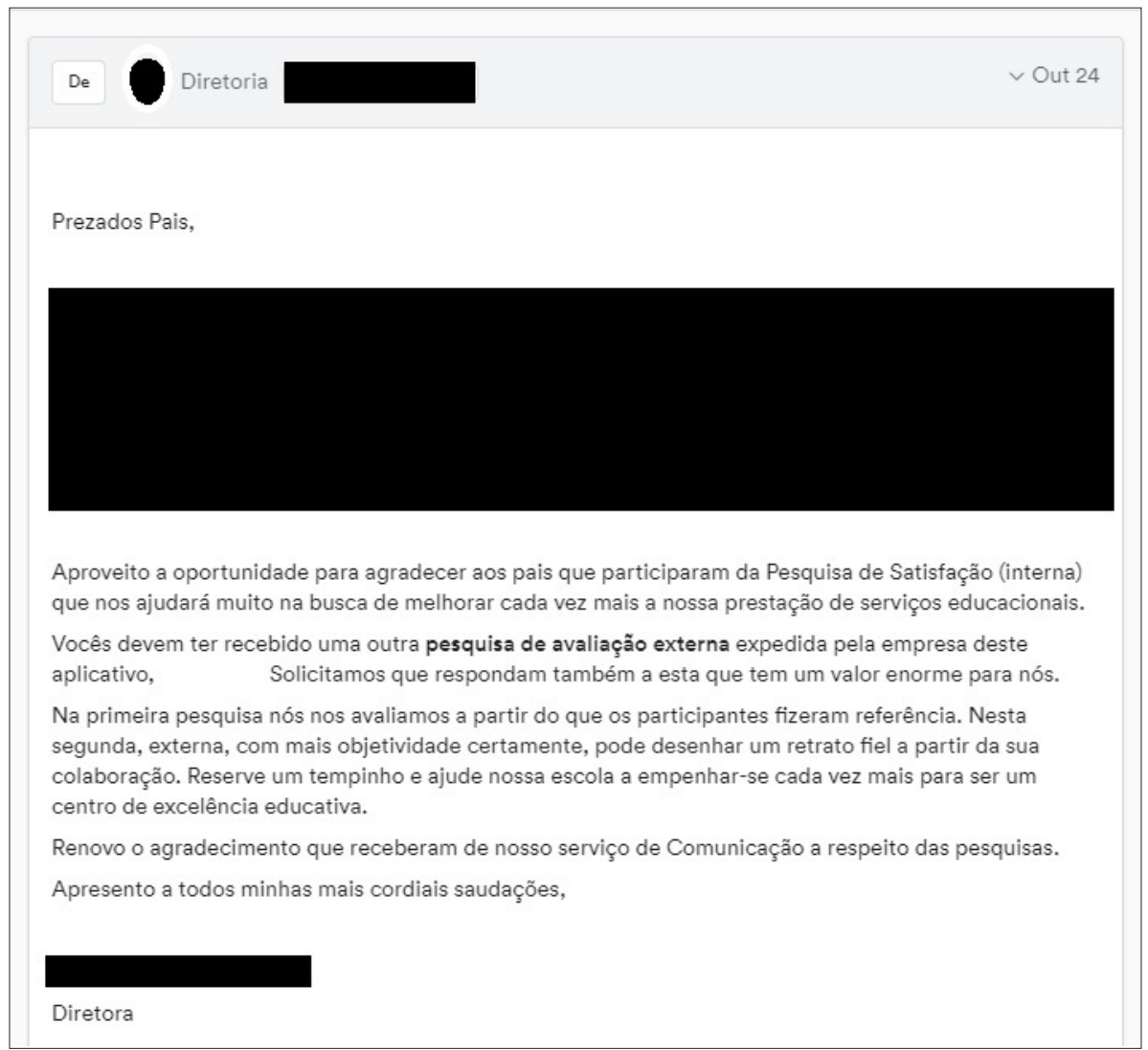

Figura 2. Comunicado de disparo da segunda pesquisa de satisfação

Fonte: Aplicativo interno de comunicação da unidade educacional

Nota: Algumas informações foram ocultadas pelo autor

De acordo com o regulamento estipulado pela empresa responsável pela pesquisa, as escolas participantes eram divididas em quatro categorias: pequenas (com até 200 alunos), médias (com até 650 alunos), grandes (com mais de 650 alunos) e extracurriculares, (instituições voltadas para cursos de idiomas, artes e outros). Para a participação ser válida, a escola deveria ter um número mínimo de respostas que garantissem margem de confiabilidade de $95 \%$ e de erro de $5 \%$. Contando com 536 famílias em sua comunidade escolar no contexto de realização da pesquisa, a unidade educativa aqui estudada precisava de 221 respostas para participar do levantamento. Atingido esse índice, a instituição faria parte de um ranking de classificação e receberia, conforme desempenho relacionado à probabilidade de a escola ser recomendada a outros pais, um certificado de qualidade ou de excelência conferido pela gestora da enquete.

A partir desse método, seria realizado o cálculo do índice Net Promoter Score (NPS), idealizado pelo pesquisador americano Fred Reichheld. Tal índice é orientado pela crença de que uma única 
pergunta pode determinar lealdade à empresa e, por consequência, satisfação em relação ao serviço por ela ofertado. Essa pergunta definitiva seria, justamente, voltada à probabilidade de indicação de uma empresa por parte dos seus clientes. As respostas à questão são, então, medidas em uma escala de 0 a 10, e os respondentes divididos em três grupos: i) os Promotores; ii) os Neutros e; iii) os Detratores. Para calcular o índice NPS, por sua vez, é preciso obter o percentual de clientes Promotores (P) e subtrair desse percentual os Detratores (D), segundo Couto (2015). Para a empresa responsável pela pesquisa aplicada na unidade educativa, os respondentes que atribuíssem valor de 0 a 6 no questionamento já citado seriam considerados detratores; aqueles que atribuíssem valor 7 ou 8 seriam considerados neutros e, por fim, os respondentes que atribuíssem valor 9 ou 10 seriam considerados promotores. Da mesma forma como aconteceu com a primeira pesquisa de satisfação realizada com os pais e responsáveis dos alunos do colégio, não foi exigida nenhuma identificação por parte dos respondentes. Por sua vez, outros resultados dessa segunda pesquisa de satisfação foram selecionados para análise, especialmente aqueles que diziam respeito a aspectos específicos do composto de marketing do colégio, como promoção, pessoas e evidências físicas.

Dada a relação entre satisfação do consumidor, produtividade e satisfação dos funcionários de uma empresa apontada por Nannetti et al. (2015), considerou-se oportuno realizar um novo levantamento sobre satisfação, dessa vez com os funcionários do próprio colégio. Essa outra pesquisa foi formulada de maneira similar ao primeiro questionário de satisfação enviado aos pais dos alunos. 0 formulário foi criado na plataforma Google Forms e encaminhado aos colaboradores por meio do aplicativo interno de comunicação. $O$ procedimento para seleção de perguntas e respostas foi igual ao adotado para as duas pesquisas realizadas com os pais dos alunos, descritas anteriormente.

Outra fonte de informações utilizada neste trabalho foi o conjunto de relatórios de transferências e de novas matrículas realizadas pela instituição nos anos de 2016, 2017 e 2018. Os dados contidos nesses documentos possibilitaram quantificar o número de egressos da instituição e visualizar as razões pelas quais famílias deixaram o colégio, fornecendo subsídio importante para vislumbrar a eficácia da escola no que diz respeito à retenção dos seus clientes e captação de novos alunos.

Dados de pesquisas de satisfação e relatórios de transferências e novas matrículas foram utilizados com objetivo de verificar fatores de descontentamento ou satisfação que poderiam transformar os clientes da unidade educacional aqui estudada em detratores ou promotores além de conjecturar sobre o seu clima organizacional.

Conjuntamente com o estudo desses levantamentos, realizou-se revisão bibliográfica sobre os temas Marketing de Serviços e Marketing Educacional a fim de identificar suas especificidades e, assim, discutir as possibilidades de ação de uma instituição de ensino da educação básica nesse setor, buscando maior fidelidade da sua clientela. Nessa direção, também verificou-se, geograficamente, o público atendido pelo colégio a partir da lista de educandos matriculados na instituição. De posse do código de endereçamento postal dos clientes, criou-se um mapa de calor ("heatmap") com as ferramentas Google Maps, Google Earth e o software QGIS com a área de atuação do colégio e identificou-se demais instituições privadas de educação básica presentes nesse espaço. 0 procedimento adotado consistiu na inserção dos CEPs dos clientes no Google Maps. A partir dos pontos referenciados na aplicação, foi gerado um arquivo .csv com esses códigos. Esse arquivo, por sua vez, foi importado para o Google Earth, com o intento de determinar as coordenadas geográficas correspondentes aos endereços. Os dados foram novamente exportados para um arquivo.csv, dessa vez por meio do Google Earth e, então, inseridos no aplicativo QGIS, juntamente com as camadas vetoriais do arruamento da cidade de Curitiba.

Com base nesse conjunto de dados, procurou-se conhecer o público da escola e discutir de forma estratégica componentes específicos do seu composto de marketing (promoção, pessoas e evidências físicas). A partir da análise das informações, foram propostas estratégias para que os pontos positivos da instituição sinalizados pelos seus clientes fossem potencializados como fatores de diferenciação frente à concorrência e, do mesmo modo, os aspectos negativos apontados, sujeitados à análise para correção tendo em vista a definição de planejamento estratégico de marketing elaborada por Kotler e Fox (1994), qual seja: o planejamento da direção global da instituição para responder seus mercados e oportunidades. 


\section{Resultados e Discussão}

Marketing consiste na definição e conhecimento de um produto ou serviço e a forma como ele é abordado e colocado no mercado para que a relação entre produto/serviço e consumidores se desenvolva adequadamente, conforme Yanaze (2011). Segundo Lovelock e Wirtz (2006) produtos ou serviços entregam benefícios aos clientes que os compram e os utilizam. Os autores pontuam que no caso de bens os benefícios são oriundos da propriedade dos próprios objetos. Já nos serviços, os benefícios são criados pelas ações realizadas pelos seus prestadores ou, ainda, pelo desempenho desses na realização do próprio serviço. Ainda segundo os autores, o serviço consiste em um ato ou desempenho oferecido por uma parte à outra e o desempenho a ele relacionado é transitório, de natureza frequentemente intangível e que não gera propriedade de qualquer fator de produção. Dessa maneira, conforme os critérios especificados por Lovelock e Wirtz (2006), tem-se que a distinção fundamental entre bens e serviços está no fato de que clientes normalmente derivam valor de serviços sem obter a propriedade de quaisquer elementos tangíveis. Las Casas (2012) destaca, nessa direção, que enquanto bens podem ser objetos, artigos, artefatos ou materiais, serviços são atos, ações ou até mesmo um esforço.

Kotler et al. (2002) salientam quatro características que marcam de forma distintiva os serviços em relação aos produtos: intangibilidade, indivisibilidade, variabilidade e perecibilidade. Para os autores, a intangibilidade significa que os serviços não podem ser provados, por exemplo, antes de serem adquiridos. Dessa forma, o prestador do serviço tem como um dos seus objetivos principais oferecer uma representação tangível que busca comunicar o processo e os prováveis resultados do que será ofertado. A indivisibilidade, por sua vez, refere-se ao fato de que os serviços não podem ser separados dos seus prestadores. Assim, o prestador acaba tornando-se o próprio serviço que oferta. Consequentemente, o profissionalismo, a aparência e a conduta do prestador são utilizadas como critérios avaliativos da qualidade da empresa de serviços em si. Essa característica está comumente associada aos setores de atendimento telefônico ou à recepção de uma empresa, por exemplo, pois seus responsáveis oferecem com frequência a primeira impressão que os clientes terão de toda a organização. A variabilidade do serviço, dada essa última característica em especial, torna-se frequente uma vez que essa é inseparável das pessoas que o realizam. Por fim, os serviços são perecíveis, o que significa que eles não podem ser armazenados para venda ou posterior uso. A perecibilidade, ainda, está ligada diretamente às variações da demanda pela prestação de um serviço específico. Afinal, conforme ela se mantém constante, o desempenho na realização do serviço tende a ser, também, constante. Já se a procura pelo serviço passar por grandes flutuações, a manutenção da coerência na prestação do serviço tende a se tornar mais difícil.

Kotler et al. (2002) destacam que o cliente que compra um serviço participa diretamente dos seus processos de orientação. Nesse sentido, as experiências pelas quais o consumidor passa geram impressões que caracterizam um momento de verdade no qual a mensagem sobre a qualidade do serviço e sua realização efetiva são colocadas lado a lado, comparadas efetivamente. Portanto, independentemente da forma como os serviços são oferecidos, o sucesso do marketing no setor está relacionado diretamente ao grau de orientação da prestação do serviço para o cliente, sendo essa característica a principal missão de organizações que nele atuam.

Se o serviço deve ser orientado para o cliente é necessário, para atendê-lo de forma adequada, saber quem ele é. Nesse sentido, observou-se a partir dos dados das fichas de matrículas dos alunos do colégio estudado que eles estão localizados, principalmente, nas regionais da Matriz e da Boa Vista do município de Curitiba. Essas regiões compreendem um conjunto de trinta bairros nas regiões norte e nordeste da cidade. O colégio está situado no bairro Juvevê (Regional Matriz) e, conforme é possível observar na Figura 3, boa parte de sua clientela reside em bairros relativamente próximos à instituição. 


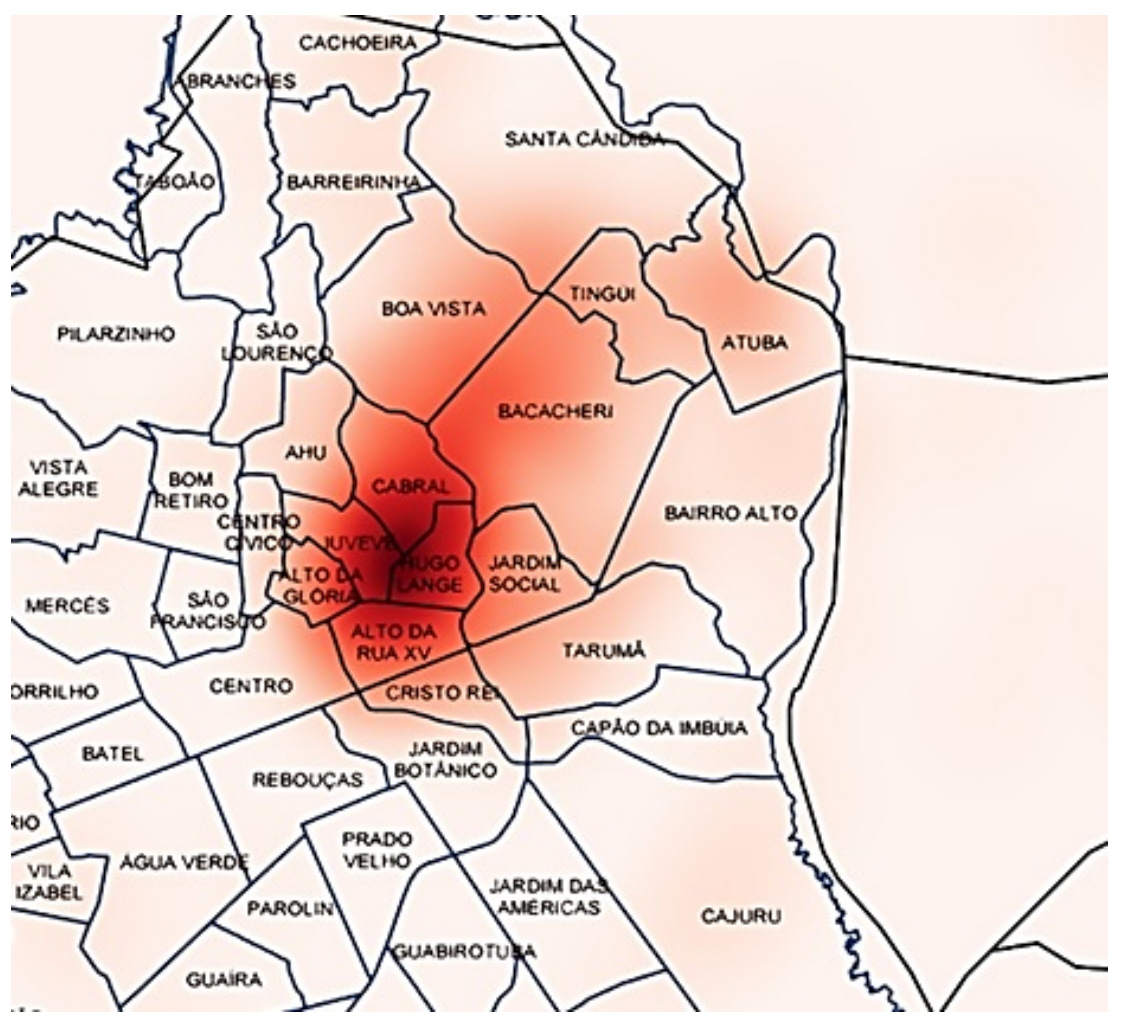

Figura 3. Mapa de calor ("heatmap") com área de clientes atendidos pela unidade educativa Fonte: Resultados originais da pesquisa

No ano de 2017 a Regional Matriz² contava com cerca de 206 mil habitantes, número que correspondia a $12 \%$ do total de moradores do município. Conforme levantamento realizado pela Agência Curitiba de Desenvolvimento e Inovação, em 2010 o rendimento médio na região foi de $\mathrm{R} \$ 6.438,71$, o maior entre todas as regionais e $71 \%$ superior ao apresentado pela cidade. Conforme dados apurados pela escola, atualmente a maioria dos pais de seus alunos possui entre 30 e 45 anos, formação universitária e suas atividades profissionais são relacionadas ao comércio e à prestação de serviços. $\mathrm{Na}$ instituição predomina a estrutura tradicional familiar, composta por pai, mãe e filhos.

Ainda em 2017, o setor de serviços era responsável por 58,3\% dos estabelecimentos econômicos na Regional Matriz. No que diz respeito à prestação de serviços educacionais, nos bairros Juvevê, Cabral, Hugo Lange, Alto da Glória, Alto da XV, Ahú, Boa Vista e Bacacheri se encontram, atualmente, 82 estabelecimentos de educação básica privada, que ofertam algum dos níveis de ensino disponibilizados pelo colégio estudado nesta pesquisa (Educação Infantil, Ensino Fundamental e Ensino Médio).

Desenhado esse cenário, realizou-se o levantamento das características mais representativas da instituição para sua clientela. Para tanto, utilizou-se os resultados das pesquisas de satisfação desenvolvidas ao longo de 2018 com os pais dos alunos do colégio. A primeira pesquisa foi feita entre os meses de julho e agosto e contou com a participação de 122 respondentes (frente aos 536 alunos matriculados na instituição). Das 536 pessoas que receberam o endereço para a pesquisa, 122 (22,7\%) responderam o formulário. É interessante notar que 414 (77,2\%) pessoas realizaram a leitura do comunicado com acesso para o questionário.

O baixo índice de respondentes dessa pesquisa sugere possíveis estratégias para que os integrantes da comunidade escolar se tornem mais engajados em enquetes futuras, algo que aumentaria a quantidade de informações disponíveis para análise do público atendido pelo colégio e possibilitaria um estreitamento das relações entre instituição e comunidade. Uma ação possível a ser adotada pela instituição nesse sentido seria aproximar o envio da pesquisa de satisfação aos eventos festivos por

${ }^{2}$ Unidade de administração descentralizada da Fundação de Ação Social (FAS). 
ela realizados, (uma Festa Junina, por exemplo) e oferecer algum brinde, como vale alimentício, aos respondentes.

Ainda sobre o número de respostas à pesquisa, é possível extrair outro dado interessante: quais são os respondentes mais engajados nessa atividade, conforme Figura 4.

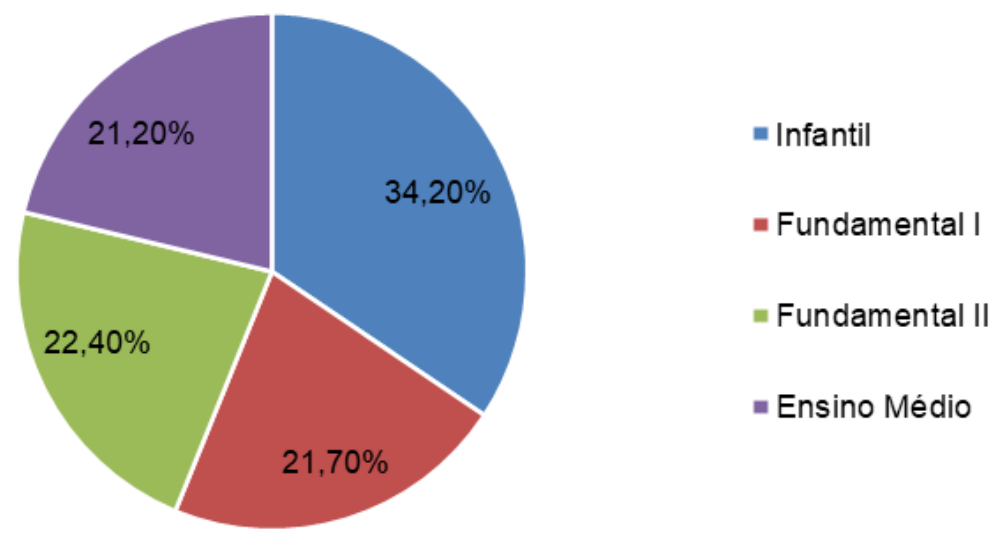

Figura 4. Engajamento na pesquisa de satisfação por segmento

Fonte: Resultados originais da pesquisa

Os pais e responsáveis dos educandos matriculados na Educação Infantil (38 alunos) foram, proporcionalmente, os que mais participaram da pesquisa, com 13 respostas (34,2\%). Os pais e responsáveis pelos educandos matriculados no Ensino Fundamental II (165 alunos) tiveram o segundo maior índice de engajamento, com 37 respostas (22,4\%). Em terceiro lugar, encontram-se os pais dos educandos do Ensino Fundamental I, segmento com maior número de alunos matriculados no colégio (239 alunos), mas com 52 respostas na pesquisa de satisfação $(21,7 \%)$. Por último, tem-se que os pais e responsáveis pelos educandos do Ensino Médio (94 alunos) tiveram um engajamento de 21,2\% na pesquisa, enviando 20 respostas. Essa tendência também foi observada na segunda pesquisa de satisfação, realizada em novembro de 2018. Nesse segundo levantamento, $49 \%$ dos respondentes foram pais de educandos do Ensino Fundamental I, 29\% pais de alunos do Ensino Fundamental II, 13\% pais de alunos do Ensino Médio e $9 \%$ pais de alunos da Educação Infantil.

Tendo em vista o número de crianças matriculadas no Ensino Fundamental I da escola ( $1^{\circ}$ ao $5^{\circ}$ ano), 239 educandos, seria possível supor que os pais desse segmento estariam mais engajados nas atividades desenvolvidas pelo colégio. Entretanto, a partir da análise das proporções de alunos matriculados por segmento em relação ao número de repostas do $1^{\circ}$ questionário de satisfação é possível observar que o maior engajamento nesta atividade aconteceu na Educação Infantil (38 educandos). Observou-se, ainda, que os pais dos educandos do Ensino Médio tiveram uma participação expressiva na pesquisa, uma vez que se comparou a quantidade de alunos matriculados (94 educandos) no segmento e o índice de respostas oriundas desse filão. Esse dado em especial é interessante, pois indica à instituição a necessidade de pensar estratégias de melhor comunicação e maior inserção desses pais na sua comunidade escolar, como a realização de projetos de integração entre família e escola.

O colégio estudado já desenvolve ações dessa natureza com pais e responsáveis da Educação Infantil ao $9^{\circ}$ ano do Ensino Fundamental. Os eventos contam com a presença de um profissional da área de educação ou psicopedagogia, que debate com pais dos alunos temas relacionados aos desafios de se educar os filhos. Tendo em vista o engajamento na pesquisa de satisfação por segmento de ensino, a escola poderia estender ou adaptar tais eventos aos pais e responsáveis pelos educandos do Ensino Médio, abrindo espaço para a participação desse segmento. Nesse sentido, as ações poderiam abordar temas comuns e pertinentes à faixa etária desses alunos, como saúde e sexualidade ou orientação vocacional frente à proximidade dos concursos vestibulares, por exemplo. Evidentemente, a disposição da instituição em realizar esses encontros e convidar as famílias não significa engajamento automático dos pais aos projetos. Assim, cabe ao colégio identificar fatores para a não adesão dessas pessoas nessas atividades, considerando a atratividade da proposta, seus objetivos específicos e horários de realização, entre outros fatores. 
Os demais dados das pesquisas de satisfação realizadas indicam que 63,1\% (77 respondentes) consideraram o ensino como a principal qualidade do colégio. Já 14,8\% dos respondentes (18 pessoas) consideraram o corpo docente como a principal qualidade da instituição. $O$ atendimento personalizado foi colocado acima das outras qualidades citadas por $18 \%$ dos respondentes ( 22 pessoas). E, por fim, apenas, $4,1 \%$ (5 respondentes) atribuiu ao preço o primeiro lugar no que diz respeito à principal qualidade da escola.

A segunda pesquisa de satisfação realizada pelo colégio contou com 259 respondentes (mais que o dobro de participantes da pesquisa aplicada entre julho e agosto do mesmo ano) e apresentou, conforme Figura 5, dados similares no que diz respeito à avaliação geral da escola ${ }^{3}$.

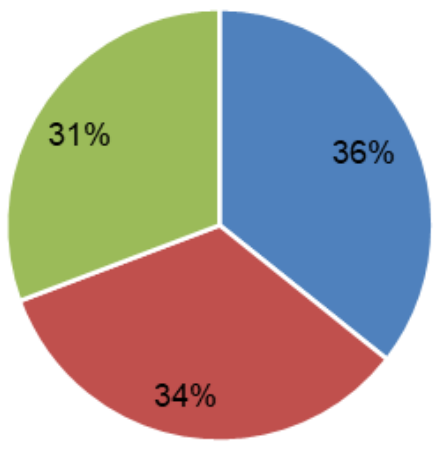

$$
\text { - Comprometida com o Ensino = Humanizada " Preza princípios e valores }
$$

Figura 5. Três características que melhor representam a essência da escola

Fonte: Relatório Individual Escolas Exponenciais (2018)

Uma instituição humanizada, comprometida com o ensino e que preza por valores e princípios. As três características reforçadas pela comunidade escolar do colégio refletem diretamente os principais objetivos da missão educativa apresentada pela instituição. De acordo com sua proposta pedagógica, educar para a vida e para a felicidade por meio da integração de valores e conhecimentos são seus pontos norteadores e o resultado esperado do processo educativo é que os alunos sejam capazes de exercer sua individualidade e promover a interdependência das pessoas para que se tornem, então, sujeitos da sua própria história.

Conforme apontado por Machado (2009), a Missão é a própria essência de uma organização. É ela que norteia, inclusive, o desenvolvimento da estratégia a ser utilizada pela instituição, definindo fatores fundamentais para que esta obtenha sucesso. Para Scott et al. (1998) missão é a síntese de como os clientes e colaboradores (estes em seus respectivos grupos) percebem a empresa. Assentada em valores essenciais, a missão também inclui como o ambiente maior percebe seu propósito. Machado (2009) ainda destaca que a missão difunde o espírito de uma empresa de forma a concentrar esforços para que objetivos sejam alcançados.

Uma educação baseada em valores éticos conforma o sentido da própria instituição aqui estudada, ou ainda, seu propósito básico. Para o colégio em questão, a educação é voltada para a vida e não apenas para obtenção de resultados, como aprovações em concursos vestibulares ou para a conquista de posições mais altas em rankings de avaliações como o Enem. Esses últimos aspectos, evidentemente, são importantes tendo em vista que a escola possui turmas de ensino médio e realiza atividades específicas de preparação dos alunos para concursos vestibulares e para o Exame Nacional do Ensino Médio. Entretanto, as aprovações não são vistas como fins em si mesmas. Elas são tidas para a instituição como reflexos de um projeto educativo desenvolvido desde à Educação Infantil.

${ }^{3} \mathrm{~A}$ questão, nesse caso, era sobre a essência da escola e permitia a seleção de uma a três características entre o grupo a seguir: Inovadora; Criativa; Humanizada; Focada em resultados; Segura; Comprometida com o ensino; Ética; Referência; Confiável; Inclusiva; Sustentável; Tradicional; Acolhedora; Familiar; Moderna; Participativa; Visionária; Preza princípios e valores; Religiosa; Formação integral; Internacional. 
De acordo com Carneiro (2015), no mercado educacional as instituições devem traçar planos de ações para que atraiam a atenção de potenciais consumidores (alunos), estabeleçam um posicionamento e se diferenciem no mercado. Assim sendo, a missão da unidade educativa aqui estudada pode se tornar propriamente um fator de diferenciação frente às instituições de ensino cujo objetivo maior é garantir aprovações em concursos ou médias altas no ENEM, por exemplo.

Ainda referente a essa questão, tem-se que a imagem e reputação da instituição possuem papel crucial no processo de posicionamento no mercado, pois compreende-se que um posicionamento adequado fomenta uma boa reputação, algo que, por sua vez, só é possível de ser alcançado quando as instituições atingem as expectativas positivas dos seus consumidores. Ou seja, as pessoas passam a confiar na instituição, segundo Nguyen e LeBlanc (2001). Aqui, a missão, ou o propósito básico que a instituição possui, é fundamental, pois é através dela que os colaboradores e clientes sentem-se satisfeitos em fazer parte da instituição ou em serem atendidos por ela.

O Marketing Educacional visa permitir, justamente, o maior sucesso do atendimento da missão da instituição em detrimento da simples busca pelo aumento de vendas (crescimento do número de matrículas). Promoções muito agressivas, nesse sentido, tendem a ser mais prejudiciais do que benéficas, uma vez que podem atrair clientes que não se preocupam ou não estabelecem qualquer relação com os propósitos/missão defendidos pela empresa (Kotler e Fox, 1994). Assim, tais clientes podem deixar a instituição quando suas expectativas não forem atendidas. Para um colégio cuja missão é orientada por uma noção de projeto educativo desenvolvido a longo prazo (da Educação Infantil ao final do Ensino Médio) esse perfil de cliente é, certamente, desfavorável.

Tendo em vista as características apontadas pela comunidade escolar em uma das pesquisas de satisfação e sua missão, pode-se afirmar que o posicionamento da escola foi realizado de forma adequada. A percepção dos clientes de que o colégio é humanizado, comprometido com o ensino e que prioriza valores sugere que a comunicação (promoção) está sendo eficaz, uma vez que as características apontadas pelos pais e responsáveis refletem, justamente, o propósito que a instituição estabeleceu para si.

Seguindo os questionários das pesquisas de satisfação realizadas em 2018 tem-se que, no primeiro levantamento realizado com 122 participantes, a avaliação do corpo técnico docente da instituição foi positiva. Nesse critério, 74 pessoas (60,6\%) consideraram os professores ótimos, 41 (33,6\%) estavam satisfeitos com o corpo docente do colégio e $7(5,7 \%)$ dos 122 respondentes disseram que os professores poderiam melhorar. Os educadores da instituição também foram avaliados em alguns aspectos específicos, conforme Figura 6.

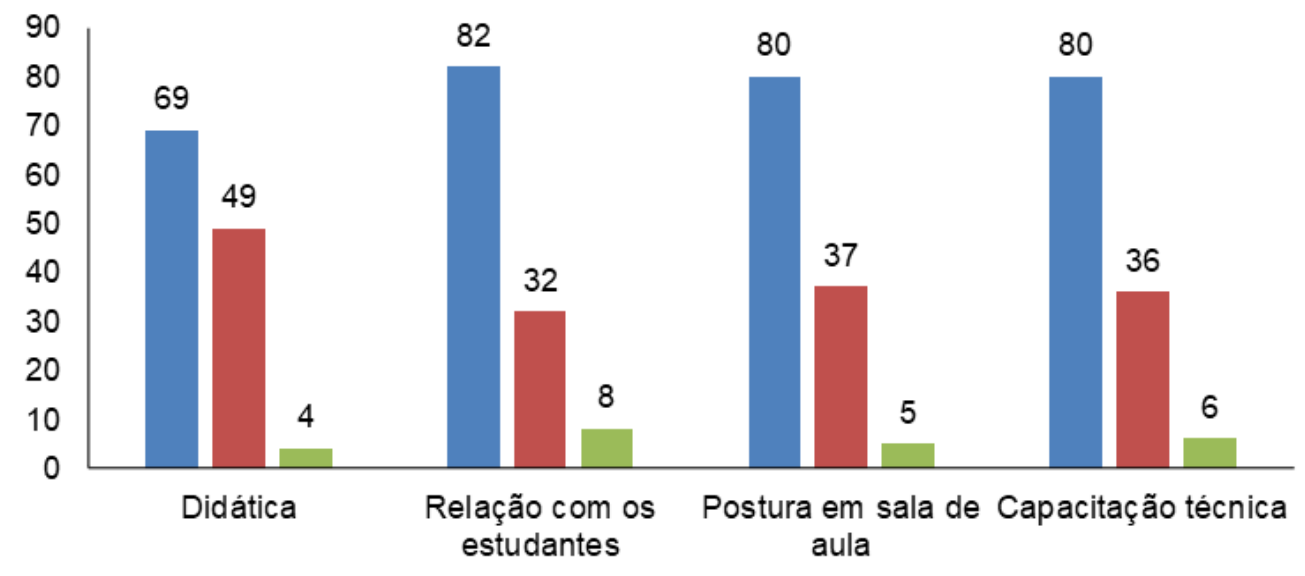

घÓtimo @ Satisfatório $\quad$ Precisa melhorar

Figura 6. Avaliação dos educadores

Fonte: Resultados originais da pesquisa

O quesito com o número de respostas mais equilibrado entre as categorias ótimo e satisfatório foi o da didática, no sentido de manter o grupo de estudantes coeso e interessado durante as aulas, o que indica uma avaliação mais cautelosa dos respondentes sobre esse aspecto. Já no segundo levantamento 
realizado, com um número maior de participantes, a qualidade de ensino da escola foi considerada muito boa por $51 \%$ dos respondentes e excelente por $35 \%$, enquanto $10 \%$ avaliaram esse quesito como bom e $3 \%$ como regular.

No entanto, demais dados da segunda pesquisa de satisfação mostram que o principal motivo pelo qual os pais consideravam retirar seus filhos da escola era, justamente, a falta de qualificação de professores ou a percepção de que a equipe docente era desatualizada. O levantamento apontou que $26 \%$ dos respondentes tinham essa perspectiva sobre os educadores da instituição. Dessa forma, apesar da qualidade de ensino ser bem avaliada pelos pais, estes têm ressalvas quanto à qualificação dos professores.

Benini e Scheid (2013), em estudo sobre fatores de influência na escolha de escolas particulares no município de Roca Sales, chegaram à conclusão de que a composição do grupo de professores e sua qualificação era o fator mais relevante no processo de escolha de uma escola privada. Amparados na literatura especializada, os autores apontam que os serviços educacionais estão sujeitos às compras comparadas e não de conveniência. Portanto, determinados aspectos do serviço precisam estar adequados a modelos ou padrões de qualidade, fatores que muitas vezes são mais relevantes que o preço do próprio serviço ofertado. Conforme os dados auferidos das pesquisas de satisfação, pode-se afirmar, de acordo com Kotler e Fox (1994), que um grupo de professores qualificado e atualizado constitui um desejo específico nesse contexto. Dessa maneira, para os clientes do colégio estudado, um bom ensino não basta. É necessário, também, que os responsáveis por ministrar esse ensino mantenham-se constantemente atualizados, mesmo que sua prática pedagógica seja considerada muito boa. Aqui, no entanto, tendo em vista a amplitude da pergunta presente na segunda pesquisa de satisfação aplicada no colégio, a seguinte reflexão se faz possível: a percepção por parte dos seus clientes de que a equipe de professores é desatualizada, está relacionada à formação acadêmica em si (como uma exigência de que os educadores devem realizar cursos de pós-graduação e se atualizarem academicamente) ou se refere ao uso de tecnologias de comunicação e informação na sala de aula? Talvez, os dois aspectos constituam a demanda dos clientes.

Diversos estudos já foram realizados sobre a importância da formação continuada para os profissionais da área da Educação. Além da renovação de conhecimentos, o contínuo aperfeiçoamento profissional dos professores amplia e aprimora as práticas pedagógicas. Nesse sentido, o incentivo ao uso constante de diversas Tecnologias de Informação e Comunicação (TDIC's) é um aspecto importante para o aprimoramento profissional dos educadores. Além de possibilitar contato com ferramentas que podem agilizar o trabalho burocrático, cursos de capacitação sobre as TDIC's podem revelar-se aos professores instrumentos de ensino que permitem o enriquecimento de uma prática educativa centralizada efetivamente nos próprios alunos.

A presença em debates, círculos de palestras e conferências sobre temas ligados à área da Educação também é um elemento importante no que diz respeito à atualização docente, assim como a realização de cursos de pós-graduação e o aprofundamento em áreas de atuação específicas. 0 leque de possibilidades de aprimoramento profissional, assim, é bastante amplo, e o incentivo dos gestores de uma instituição de ensino a sua busca pode gerar resultados positivos para a própria empresa. Afinal, funcionários bem capacitados tendem a prestar serviços mais qualificados. Algumas ações que podem ser citadas nesse sentido são: i) criação de projetos de capacitação continuada dos professores por meio de convênios e parcerias com instituições de ensino superior; ii) desenvolvimento de programas de benefícios - que não precisam ser necessariamente financeiros - para educadores que investem em seu aprimoramento acadêmico; iii) realização de cursos de aperfeiçoamento na própria unidade de trabalho; iv) criação de planos de carreira com vistas a recompensar funcionários que concluem cursos de pós-graduação e; v) oficinas voltadas ao uso de TDIC's em sala de aula.

Essas ações devem ser pensadas como investimentos na imagem da própria empresa e não como gastos, uma vez que programas de qualificação e formação continuada de colaboradores se adequam, justamente, a uma das principais demandas dos clientes da instituição estudada. Tais medidas ainda possibilitam o aumento do capital intelectual da empresa que, para Grönross (2003), é composto pelas pessoas que formam uma determinada organização, a sua cultura e um conjunto de valores que não pode, necessariamente, ser contabilizado. Bertolla et al. (2015) destacam que esse capital intelectual 
pode ser, inclusive, utilizado como recurso importante para a retenção de clientes. Lovelock e Wirtz (2006) salientam que empresas de sucesso dedicam boa parte dos seus esforços a características importantes desse aspecto do composto de marketing. Dessa maneira, ações de capacitação de pessoal geram impacto positivo na forma como a qualidade do serviço é avaliada pelos clientes. Motivação, capacitação e treinamento, nesse sentido, são fatores importantes no que diz respeito a qualidade da prestação de serviços em um cenário de alta competitividade, como é o caso do mercado da educação básica, e devem ser sempre considerados por organizações que nele atuam.

Agora, serão analisados outros quatro fatores que foram pontuados pelos pais como motivos para possível cancelamento das matrículas na escola estudada. A pouca abertura para relacionamento com aqueles que atuam diretamente com seus filhos correspondeu à $23 \%$ das respostas sobre o tema. Busca de performance em vestibulares, opções de horários incompatíveis e a falta de investimentos em melhorias e inovação corresponderam, cada um dos fatores, a $17 \%$ das respostas ${ }^{4}$. A partir desses dados, a unidade educativa estudada pode adotar algumas medidas para solução desses problemas pontuados pelos pais.

No que diz respeito à proximidade com os educadores, o colégio poderia convidar seus professores a participarem de mais encontros cujo objetivo seja fortalecer a integração entre família e escola. Tais atividades, desenvolvidas na própria escola, poderiam se tornar, assim, momentos de troca profícua entre docentes, pais e responsáveis. Além das confraternizações realizadas pela instituição, como a Festa Junina marcada por grande presença de professores, que desempenham funções que possibilitam a realização do próprio evento, e das reuniões para entrega de resultados, ao final de cada trimestre letivo, esses momentos adicionais poderiam ampliar esse relacionamento demandado pelos pais. Evidentemente, essa é uma medida que precisaria ser analisada com cautela pela gestão da unidade educativa, uma vez que a questão da disponibilidade de horários dos docentes, assim como a remuneração para essas atividades, precisaria ser avaliada.

Sobre a melhoria de performance em vestibulares, o colégio procura, há algum tempo, atender essa reivindicação da sua comunidade de pais e responsáveis. Uma das medidas adotadas nesse sentido foi a reestruturação da forma como o Ensino Médio é ofertado. 0 terceiro e último ano de estudo desse segmento foi convertido em uma espécie de período preparatório para esses exames, para o Enem e para o ingresso na vida acadêmica. Assim, na terceira série do Ensino Médio os alunos da instituição realizam uma retomada de todos os conteúdos abordados nas duas primeiras séries. Além disso, na escola são ministradas aulas específicas sobre conteúdos mais exigidos em vestibulares, com o desenvolvimento de trabalhos de iniciação científica como forma de preparo ao ingresso na vida acadêmica e incentivo à pesquisa, são realizadas aulas especiais para cada área do conhecimento, desenvolvidos e aplicados simulados, efetivadas palestras sobre cursos universitários em parceria com Instituições de Ensino Superior (IES) e a participação em feiras de profissões de grandes IES da cidade de Curitiba é estimulada. Os resultados auferidos desses programas de ação realizados no Ensino Médio, por sua vez, são considerados satisfatórios pela gestão da unidade educacional e a grande maioria dos seus estudantes é aprovada em vestibulares.

As conquistas alcançadas nesse aspecto são divulgadas no espaço físico do colégio, seu site e suas redes sociais. Dessa maneira, é possível pensar que parte da insatisfação dos pais com o desempenho da instituição em vestibulares esteja associada com aspectos da comunicação/promoção desses resultados. É comum que, na cidade de Curitiba, instituições privadas de educação básica com preparação específica (os chamados cursinhos) para o vestibular invistam muito em publicidade baseada nos números de aprovações alcançadas em concursos vestibulares. Muitas dessas escolas/empresas, no entanto, possuem grande número de alunos matriculados em diversas sedes espalhadas pela cidade, algo que contrasta diretamente com a realidade da instituição aqui analisada. Comparar quantidade de aprovações alcançadas por essas grandes redes e a unidade educacional aqui estudada, portanto, não é possível.

${ }^{4}$ Opções disponíveis para escolha (podendo cada responsável selecionar de uma a três opções): Falta de investimento em melhorias e inovação; Pouca abertura para relacionamento com aqueles que atuam diretamente com seu filho(a); Atividades pedagógicas pouco divulgadas ou com informações incompletas; Tratamento impessoal ou falta de atenção com seu filho(a); Bullying com o filho(a); Baixa qualidade de ensino; Busca de performance nos vestibulares; Busca por mais segurança para os filhos; Localização distante de sua casa ou de seu trabalho; Infraestrutura inadequada e poucos espaços abertos; Falta de qualificação de professores e/ou equipe desatualizada; Falta de organização e disciplina, com excesso de liberdade; Incompatibilidade ideológica; Opções de horários incompatíveis; Falta de identificação com o curso; 0 colégio não possui o segmento do meu filho. 
Não obstante, a comunicação dos resultados alcançados pelos alunos do colégio pode ser ampliada e enriquecida como forma de apresentar à comunidade educativa que bons desempenhos em concursos fazem parte, sim, da realidade escolar da instituição. Nessa direção, os resultados positivos alcançados pelos alunos podem ser também divulgados por e-mails, em painéis afixados nas áreas de acesso ao colégio e nas salas de aulas dos estudantes, principalmente, do Ensino Médio e do $9^{\circ}$ ano do Ensino Fundamental. Ex-alunos que ingressaram em universidades e faculdades poderiam ser convidados pela direção e coordenações a conversar com os atuais estudantes do Ensino Médio sobre sua preparação, realizada no colégio, para a vida acadêmica. Testemunhos, diálogos e debates tornam-se mais efetivos em uma ação de comunicação dessa natureza do que o simples uso de cartazes com fotos e indicadores de aprovação, pois por meio do diálogo entre ex-alunos e atuais alunos há o compartilhamento de experiências que tem, como pano de fundo, as próprias ações do colégio.

Os outros dois pontos negativos apontados pelos pais na pesquisa de satisfação também demandam cuidados por parte do colégio, evidentemente. No que diz respeito à incompatibilidade de horários, é possível deduzir que essa insatisfação é mais perceptível entre os pais dos alunos do Ensino Fundamental. A escola oferta os níveis de ensino em horários distintos. No período da manhã, por exemplo, não existem turmas de Educação Infantil. Já no período da tarde concentra-se a grande maioria das turmas do chamado Ensino Fundamental I ( $1^{\circ}$ ao $5^{\circ}$ ano), enquanto no turno da manhã há apenas uma turma de $5^{\circ}$ ano. $\mathrm{O}$ Ensino Fundamental II, por sua vez, é inteiramente ministrado no período matutino, situação igual à do Ensino Médio que, em dois dias da semana, participa de aulas de inglês no período da tarde. Dessa maneira, os educandos que concluem o $5^{\circ}$ ano no período da tarde (maioria) precisam realizar a mudança de turno. Instituições privadas de educação básica localizadas nas proximidades do colégio, que inclusive praticam preços e possuem estruturas similares ao do caso aqui estudado, ofertam o segundo segmento do Ensino Fundamental tanto no período matutino quanto no vespertino, tornandose, possivelmente, atrativas para os clientes insatisfeitos.

A solução mais evidente para essa questão de incompatibilidade de horários pontuada pelos pais seria a disponibilização, por parte da instituição, de turmas do Ensino Fundamental II em ambos os períodos. No entanto, a viabilidade econômica dessa medida precisa ser cautelosamente analisada, uma vez que o número de alunos matriculados nessas eventuais turmas novas pode gerar mais despesas do que acréscimos ao faturamento da empresa. Os fatores a serem considerados nesse sentido são vários, tais como: número de professores a serem contratados, espaço físico adequado disponível, disponibilidade de funcionários de suporte e atendimento aos alunos (enfermaria, alimentação e zeladoria), entre outros.

No que diz respeito à falta de investimentos em melhorias e inovação cabe destacar que a escola tem procurado atender a demanda dos pais. O colégio foi fundado em 1939 e sua estrutura física é grande, contando com bosque, quadras poliesportivas, ginásio coberto, pátios, salas de atendimento, auditório, laboratório de informática e de ciências, biblioteca, salas de arte e música, enfermaria, e um refeitório destinado à Educação Infantil. As salas de aula são todas equipadas com um computador e uma televisão e, algumas delas, contam também com projetor e caixas de som. Além disso, o colégio também possui um sistema integrado de áudio e vídeo, além de câmeras de segurança nos corredores das salas de aula e recepção. Obras de preservação dessa grande estrutura são continuamente realizadas e a instituição possui uma equipe de funcionários que prestam serviços de zeladoria e manutenção dos seus espaços e equipamentos. Algumas obras de maior porte, que gerarão mudanças estruturais, fazem parte dos planejamentos da unidade educativa, mas aguardam aprovação da prefeitura do município de Curitiba para serem iniciadas.

Esse cuidado com a manutenção e a revitalização da instituição é um aspecto importante, pois influencia diretamente a percepção da comunidade escolar. Segundo Lovelock e Wirtz (2006), apesar dos elementos intangíveis dominarem o processo de criação de valor dos serviços, elementos tangíveis - como as salas de aula e laboratórios, por exemplo - também fazem parte desse processo. 0 cuidado voltado aos espaços físicos do colégio, dessa forma, pode ter dupla função: ao mesmo tempo em que falam de organização e de planejamento geram instalações físicas renovadas, elementos que são palpáveis aos clientes. Nesse sentido, eventos variados poderiam ser organizados pela equipe gestora da empresa nos espaços renovados como forma de salientar que os investimentos em infraestrutura demandam, também, sua atenção. Dessa maneira, a escola pode conseguir índices maiores de satisfação junto à comunidade de pais, responsáveis e professores, uma vez que esse indicador também é influenciado por fatores como aparência (Lovelock e Wirtz, 2006). 
Apesar desses apontamentos específicos realizados pelos pais, o principal motivo que os levaria a considerar a troca do prestador de serviço de educação básica, de acordo com 61\% dos 259 respondentes do segundo levantamento de satisfação, era econômico. Esse fator pode estar relacionado ao elevado grau de endividamento das pessoas no estado do PR. Dados apurados pela Federação de Comércio de Bens, Serviços e Turismo do Paraná (Fecomercio-PR, 2019) e pela Confederação Nacional do Comércio de Bens, Serviços e Turismo (CNC) mostram que, em fevereiro de 2019, 90,8\% das famílias paranaenses estavam endividadas e, dessas, $26,5 \%$ tinham contas em atraso, tendência que já se observava em anos anteriores. 0 levantamento mostrou, ainda, que $11,4 \%$ das famílias com contas em atraso não possuíam condições de pagar essas dívidas. Entre os tipos mais comuns de endividamento encontravam-se o cartão de crédito e os financiamentos de automóveis e casas. Apesar do atraso de pagamento das mensalidades em escolas particulares não perfilar entre os dados apurados, o comprometimento do orçamento familiar com outras dívidas pode, evidentemente, impactar o faturamento dessas instituições de ensino.

Outro ponto importante levantado pela segunda pesquisa de satisfação diz respeito aos motivos pelos quais, quando há a intenção de trocar de instituição, estudantes consideram sair da escola 5 . Mesmo que $92 \%$ dos respondentes tenham apontado que os pais são os decisores na definição da escola, avaliar a percepção dos alunos sobre aspectos da instituição é importante. Nesse sentido, 50\% desses respondentes apontaram que seus filhos pretendiam deixar a escola por conta da falta de qualificação ou atualização da equipe de professores, número amplamente maior ao próprio número de pais que apontaram essa mesma preocupação (26\%). Os outros $50 \%$ desses respondentes indicaram que os filhos pensavam em deixar a instituição por conta da influência de amigos.

Tanto os pais quanto os alunos, a partir dos dados indicados, demandam da instituição uma equipe docente qualificada e atualizada. Assim, cabe à escola, como já exposto anteriormente, investir em programas de formação continuada dos educadores e divulgar a inserção do seu corpo docente nas atividades de capacitação. Dessa maneira, as próprias ações de capacitação dos educadores poderiam ser expostas em murais nos corredores e salas de aula, assim como os resultados positivos alcançados pela escola em concursos vestibulares, seu envolvimento em programas e ações condizentes com sua missão entre outros aspectos que podem reforçar a sua marca perante seus educandos. Tais medidas podem alterar a percepção dos alunos em relação ao colégio. Assim, o reforço da imagem da unidade educativa e a realização de ações com fins a aumentar a satisfação dos clientes tende a servir como barreira à concorrência, tendo em vista que clientes satisfeitos tornam-se clientes fiéis, uma vez que satisfação e fidelidade estão, segundo Heskett et al. (2008), diretamente ligadas.

Conforme apresentado anteriormente, uma pesquisa de satisfação também foi realizada com os colaboradores da unidade educacional aqui estudada. Entre os colaboradores, 42 responderam ao questionário que, a exemplo da pesquisa realizada com os pais dos educandos matriculados, foi encaminhado por link através do aplicativo interno de comunicação utilizado na escola. 0 engajamento dos respondentes chegou a $67,7 \%$, entre os quais $78,6 \%$ trabalhavam na área pedagógica (professores ou orientadores e coordenadores) e $21,4 \%$ na área administrativa.

A primeira questão da pesquisa direcionada aos colaboradores procurava identificar se estes indicariam a empresa na qual trabalham a algum amigo como um lugar a se trabalhar, conforme uma escala de 0 a 5. 83,3\% (35 pessoas) dos respondentes atribuíram valor 5 a questão, enquanto 16,7\% (7 pessoas) atribuíram valor 4. Resultado praticamente idêntico foi observado quando a pesquisa indagou os respondentes se estes indicariam os serviços pedagógicos prestados pela escola a algum amigo. Dessa vez, 85,7\% (36 pessoas) atribuíram valor 5 na questão, enquanto 14,3\% (6 pessoas) valor 4 . Os dados indicam, nesse sentido, que os colaboradores se encontravam majoritariamente satisfeitos em relação à instituição, tendência que também predominou entre os pais dos alunos.

Para os colaboradores, tanto do setor pedagógico como do setor administrativo, a unidade educacional é vista como uma instituição que contribui para + sua formação profissional. No entanto, de que maneira ocorre esse investimento que é percebido pelos profissionais que atuam na unidade 
educativa? O colégio possui algumas ações no sentido de capacitar tecnicamente seus funcionários. Durante a realização das chamadas semanas pedagógicas (que acontecem em duas semanas do ano, no início e ao término do primeiro semestre letivo) são realizadas palestras de temas pertinentes tanto às ações pedagógicas dos educadores quanto às ações administrativas da instituição. A escola, inclusive, possui parcerias com universidades que ofertam encontros de atualização docente, círculos de debates e palestras, em algumas ocasiões, na própria unidade educacional. Uma das faculdades parceiras da instituição também oferece descontos para a realização de cursos de graduação e pós-graduação para os funcionários da escola.

Frente a esse cenário, pode-se fazer a seguinte pergunta: o corpo técnico docente da unidade educacional aqui estudada participa, efetivamente, desses momentos de atualização e capacitação ou, ainda, consegue ingressar em novos cursos superiores ou de pós-graduação? Se a resposta for negativa, quais são as razões que impossibilitam a sua adesão às atualizações pedagógicas ou a cursos de especialização, por exemplo? Por outro lado, se a resposta for afirmativa, por quais motivos as capacitações pedagógicas não estão impactando positivamente a percepção dos pais e, principalmente, dos educandos atendidos conforme dados das pesquisas de satisfação? Nesse sentido, cabe questionar, por exemplo, se as semanas pedagógicas estão sendo, realmente, proveitosas pedagogicamente ou se estão apenas servindo como meio para se exigir e/ou cumprir uma determinada carga horária. Ou o problema estaria relacionado a uma questão de comunicação do colégio com as famílias, no sentido de aumentar a divulgação da participação do seu corpo técnico docente nos momentos de atualização pedagógica? Ou, ainda, a forma como a divulgação dessas ações acontece não corresponde às práticas efetivas adotadas pelos docentes em sala de aula e pelos demais colaboradores do setor administrativo? Tais questões podem ser apuradas pela instituição, possibilitando maior compreensão desse aspecto do composto de marketing.

Os pontos negativos mais destacados pelos pais nas pesquisas de satisfação, especialmente em sua segunda versão, consolidaram-se em motivos para que o colégio perdesse alunos matriculados? Qual o papel da capacitação dos professores nesse cenário? Os dados referentes às transferências realizadas no ano de 2018 não foram totalmente apurados pela escola, mas os números disponibilizados mostram que das 74 saídas apenas três (4\%) foram motivadas por questões pedagógicas, como metodologia de ensino. No levantamento realizado pela instituição predominam como causas de transferências a questão financeira (27\%) e a mudança de cidade/endereço (24\%). O levantamento das transferências realizadas no ano de 2016 mostrou que $23 \%$ das saídas de alunos da instituição ocorreu por questões financeiras. Em 2017 a situação foi similar: a questão financeira foi uma das principais razões pelas quais famílias cancelaram suas matrículas no colégio.

Ainda de acordo com os dados apurados pela escola, em 2016,16\% das transferências aconteceram por conta de mudança de estado ou cidade dos alunos. Apenas 3\% dos responsáveis que indicaram as razões das transferências em 2016 atribuíram a saída da instituição às questões pedagógicas que, dada a amplitude do termo adotado no levantamento, podem estar relacionadas com alguma crítica aos educadores. Para o mesmo ano, $4 \%$ dos alunos transferidos buscavam preparação para vestibulares e apenas $1 \%$ relatou que a saída da escola era motivada por incompatibilidade de horários, desejando que a instituição ofertasse $\circ 6^{\circ}$ ano do Ensino Fundamental no período vespertino. Falta de investimentos e melhorias e de um relacionamento mais próximo com a equipe pedagógica não foram listados como causas para cancelamento de matrículas.

Já em 2017, apenas dois casos relacionados às questões pedagógicas foram observados, conforme informações da própria escola. Porém, certa insatisfação com o corpo técnico docente, especialmente em relação à Orientação Educacional, foi apontada pelos pais na medida em que transferências foram listadas por conta de problemas com esse setor da instituição. Na unidade educacional aqui estudada, o orientador educacional tem, conforme proposta pedagógica, a função de acompanhar o educando no desenvolvimento da sua personalidade, auxiliando o processo de ensino-aprendizagem na medida em que atua como um elo entre a família, o educando e o educador. Tendo em vista as transferências causadas, provavelmente, por causa de falhas da orientação educacional, cabe perguntar se o elo priorizado na proposta pedagógica da instituição foi quebrado, suscitando, caso a resposta seja afirmativa, possíveis alterações no setor. 
Sendo assim, a questão relacionada à falta de capacitação e qualificação dos educadores não aparece como causa efetiva, conforme dados do colégio, para a realização de transferências no triênio 2016, 2017 e 2018. A questão financeira e as mudanças de endereço foram muito mais impactantes nesse sentido. Não obstante, os investimentos em qualificação e capacitação docente não devem ser desconsiderados, pois constituem iniciativas importantes para aprimoramento do seu corpo técnico docente, além de aumentarem o grau de satisfação dos seus clientes.

Outro indicativo interessante presente no levantamento de transferências no ano de 2016 é o de saídas relacionadas à adaptação dos educandos. Totalizando $9 \%$ das transferências, esse indicador sugere que questões comportamentais foram, possivelmente, os fatores motivadores das saídas. Aqui, algumas questões se fazem pertinentes, como: por quais razões o educando não se adaptou ao colégio? Existiam problemas de relacionamento desses alunos com outros colegas? Existiam problemas de relacionamento desses educandos com educadores ou outros colaboradores da instituição? Essas perguntas são relevantes, pois, em vista dos dados é possível afirmar que as questões comportamentais apontadas não aparentam ligação, pelo menos direta, com aspectos pedagógicos, como baixo desempenho escolar ou insatisfação com a proposta pedagógica e metodologia adotada pela instituição.

A partir dessas informações é importante observar o desempenho da escola estudada no que diz respeito à retenção e captação de novos alunos. Nessa direção, apesar do elevado número de transferências realizadas em 2016 (120), para o ano de 2017 a quantidade de rematrículas foi ligeiramente superior ao índice alcançado no ano anterior. De acordo com as informações coletadas, para o ano letivo de 2016 foram realizadas 432 rematrículas. Já para 2017 tem-se que 439 famílias optaram por manter seus filhos na instituição, representando um crescimento de 1,6\%. Para o ano letivo de 2018, segundo levantamento realizado pela secretaria da unidade educativa, tem-se que 437 famílias realizaram a rematrícula, número ligeiramente inferior ao alcançado em 2017 e que representa uma perda de $0,45 \%$.

Já no que diz respeito à captação de alunos, o cenário observado para o triênio 2016, 2017 e 2018 também demanda cuidados por parte da escola. Em 2016 o colégio recebeu 310 procuras/contatos de interessados. Comparando esse número com o total de alunos matriculados naquele ano (576), tem-se que o colégio atingiu um índice de $54 \%$ de procuras em relação à quantidade de alunos então matriculados. Desses contatos, 102 matrículas novas foram feitas na instituição. Ou seja, 32,9\% dos contatos estabelecidos ao longo de 2016, conforme levantamento interno, resultaram em matrículas novas para o colégio. Esses 102 novos educandos correspondiam a $18 \%$ dos educandos matriculados na instituição. Em resumo, pode-se dizer que, em 2016, a instituição teve 142 perdas (incluindo os 22 formandos daquele ano) e, em 2017, 102 alunos novos ingressaram no colégio, o que representa uma perda de $6,98 \%$ do alunado.

Em 2017, sempre segundo dados apurados internamente, o colégio contava com 526 educandos. No mesmo ano foram realizadas 390 procuras/contatos, o que marca um crescimento de 80 contatos em relação ao ano anterior (25,8\%). Dos 390 contatos estabelecidos, 95 deles resultaram em matrículas novas para 2018. Ou seja, 24,3\% dos interessados converteram-se em educandos da escola. Essa informação é importante, pois indica queda considerável no índice de captação de novos alunos para a instituição apesar do crescimento do número de contatos. Em resumo, tais informações indicam que, por dois anos consecutivos, a escola apresentou problemas na captação de alunos.

Um relatório desenvolvido pelo setor de atendimento telefônico e presencial com os interessados em matricular seus filhos na instituição no segundo semestre de 2018 mostrou pontos sensíveis apontados pelos pais. Algumas famílias questionaram parte da estrutura física do colégio. Outras, por sua vez, pontuaram preocupações com a questão financeira e com a impossibilidade de pagamento das mensalidades. Muitos pais solicitaram, ainda, descontos maiores na taxa de matrícula e pagamento de mensalidades do que os que são comumente ofertados pelo colégio. E, tendo tais solicitações negadas, acabaram indo aos concorrentes em busca de preços menores. Nesse sentido, não é incomum, na regional na qual se encontra a escola, que instituições de ensino ofertem descontos maiores como meio de cobrir a oferta do concorrente e, assim, aumentar o seu número de matrículas. 


\section{Conclusão}

Este estudo buscou propor estratégias de marketing para uma escola de educação básica a partir do conhecimento do seu público - proporcionado por pesquisas de satisfação e de relatório internos que diziam respeito às transferências e matrículas nela realizadas. Com base nos diversos dados coletados e analisados, foi possível observar que para a clientela da unidade educativa o aspecto preço é profundamente importante na avaliação da escola ao ponto de motivar, ou pelo menos sugerir, possíveis transferências para escolas concorrentes. Dessa maneira, caberia ao colégio ingressar em uma disputa por alunos, tendo como foco a competição motivada pelo preço do serviço ofertado, ainda mais quando se observa que este fator configura como principal motivo pelo qual grupos de alunos tendem a deixá-lo? Em vistas das especificidades do setor de Educação, dos outros aspectos pontuados pelas pesquisas e pela literatura especializada, a resposta é: não. Sem dúvidas, o fator preço é profundamente relevante, porém, cabe ao colégio transformar seus atributos intangíveis mais representativos ao público (instituição humanizada, comprometida com o ensino e que preza por valores e princípios) em atributos tangíveis que justifiquem o valor da mensalidade para esses pais. Além disso, uma corrida destinada puramente à oferta de maiores descontos pode gerar graves impactos financeiros, além de transformar a escola, em certa medida, em um balcão de negócios, atraindo possíveis clientes que não se identificam com sua proposta e missão da instituição e que buscam, apenas, um preço menor para o serviço de educação básica. Nesse sentido, as ações de marketing a serem efetivadas pela unidade educativa estudada devem ser orientadas para a valorização dos conceitos mais importantes do seu projeto pedagógico, demonstrando, na sua promoção, pontos fortes que podem ser percebidos como diferenciais em relação aos concorrentes. Por fim, cabe destacar que, além de buscar novos clientes, a instituição precisa garantir, com a maior efetividade possível, a permanência dos seus atuais alunos. Ainda que o número de promotores presentes na sua comunidade escolar seja muito maior em relação ao número de detratores, a satisfação dos clientes atendidos tende a garantir sua fidelização, tornandoos agentes importantes na promoção do estabelecimento.

Contribuição dos autores: Concepção: Santos, F.F.; Marques, R.N. Coleta de dados: Santos, F.F.; Marques, R.N. Análise dos dados: Santos, F.F.; Marques, R.N. Definição da metodologia: Santos, F.F.; Marques, R.N. Redação e edição: Santos, F.F.; Marques, R.N.

Como citar: Santos, F.F.; Marques, R.N. 2021. Marketing educacional: propostas e desafios para uma instituição de educação básica. Quaestum 2: e26750592.

\section{Referências}

Agência Curitiba de Desenvolvimento e Inovação. 2010. Perfil Econômico da Regional Matriz. Disponível em: $<$ http://www.agencia.curitiba.pr.gov.br/arquivos/regionais/perfil-economico-regional-matriz.pdf >. Acesso em: fev. 18, 2019.

Benini, K.; Scheid, E. 2013. Fatores influenciadores no processo de decisão na escolha da escola de ensino particular. Revistas Destaques Acadêmicos, 1. Disponível em: <http://www.univates.br/revistas/index.php/ destaques/article/view/259/255>. Acesso em: mar. 24, 2019.

Bertolla, F.L.; Eckert, A.; Dorion, E.C.H.; Nodari, C.H. 2015. Capital intelectual como recurso na retenção de clientes. Revista Pensamento Contemporâneo em Administração, 9. Disponível em: <https://www.researchgate. net/publication/283016932_Capital_intelectual_como_recurso_na_retencao_de_clientes_INTELLECTUAL_ CAPITAL_AS_A_RESOURCE_IN_CUSTÖMER_RETENTION̄>. Acesso em: mar. 12, $20 \overline{19}$.

Carneiro, M.M.C. $\overline{2}$ 2015. Marketing educacional: Um estudo comparativo das atividades de marketing. Tese de Doutorado em Administração. Faculdade de Economia, Administração e Contabilidade, Universidade de São Paulo, SP, BR. Disponível em: <https://teses.usp.br/teses/disponiveis/12/12139/tde-22022016-130911/publico/ CorrigidaMartaMaria.pdf >. Acesso em: jan. 25, 2019.

Couto, A.F. 2015. Satisfação e Lealdade de Clientes: Îndice NPS. Monografia - Pós-Graduação em Pesquisa de Mercado Aplicada em Comunicações. Escola de Comunicação e Artes, Universidade de São Paulo, SP, Brasil. Disponível em: <http://www2.eca.usp.br/pospesquisa/monografias/Amanda\%20Falchetti\%20Couto.pdf >. Acesso em: nov. 11, 2018.

Federação de Comércio de Bens, Serviços e Turismo do Paraná [Fecomércio-PR]. 2019. Pesquisa de Endividamento e Inadimplência do Consumidor. Disponível em: <https://www.fecomerciopr.com.br/sala-de-imprensa/noticia/ parana-tem-90-das-familias-com-algum-tipo-de-divida/>. Acesso em: mar. 22, 2019.

Heskett, J.L.; Jones, T.O.; Loveman, G.M.; Sasser Jr., E.; Schlesinger, L.A. 2008. Putting the Service-Profit Chain to Work. Disponível em: <https://hbr.org/2008/07/putting-the-service-profit-chain-to-work>. Acesso em: maio $16,2019$.

Kotler, P.; Fox, K.F. 1994. Marketing estratégico para instituições educacionais. Atlas, São Paulo, SP, Brasil.

Kotler, P.; Hayes, T.; Bloom, P.N. 2002. Marketing de Serviços profissionais: Estratégias inovadoras para impulsionar sua atividade, sua imagem e seus lucros. 2ed. Manoele, São Paulo, SP, Brasil.

Las Casas, A.L. 2012. Marketing de Serviços. 6ed. Atlas, São Paulo, SP, Brasil.

Lovelock, C.; Wirtz, J. 2006. Marketing de serviços: pessoas, tecnologia e resultados. 5ed. Pearson Prentice Hall, São Paulo, SP, Brasil. 
Machado, D.S. 2009. Filosofia Institucional: Missão - Visão - Valores do sistema de bibliotecas da Universidade Federal do Rio Grande do Sul. Monografia - Especialização em gestão de bibliotecas universitárias. Faculdade de Biblioteconomia e Comunicação da Universidade Federal do Rio Grande do Sul. Disponível em: <http://www. lume.ufrgs.br/bitstream/handle/10183/18488/000730113.pdf> Acesso em: mar. 5, 2019.

Nannetti, M.A.; Mesquita, J.M.C.; Teixeira, L.A.A. 2015. A relação entre a satisfação dos funcionários e a satisfação dos clientes: estudo nas empresas de software do município de Belo Horizonte. Revista de Administração, 50: 56-72. Disponível em: <http://www.scielo.br/scielo.php?pid=S0080-21072015000100005\&script=sci abstract \&tlng=pt>. Acesso em: dez. 2, 2018.

Nguyen, N.; LeBlanc, G. 2001. Image and reputation of higher education institutions in student's retention decisions. International Journal of Education Management, 15(6): 303-311. doi: 10.1108/EUM0000000005909.

Scott, C.; Jaffe, D.T.; Tobe, G.R. 1998. Visão, Valores e Missão Organizacional: construindo a organização do futuro. Qualitymark, Rio de Janeiro, RJ, Brasil.

Yanaze, M.H. 2011. Gestão de marketing e comunicação: avanços e aplicações. 2ed. Editora Saraiva, São Paulo, SP, Brasil. 